\title{
Optimization of Pumpkin Oil Recovery by Using Aqueous Enzymatic Extraction and Comparison of the Quality of the Obtained Oil with the Quality of Cold-Pressed Oil
}

\author{
Iwona Konopka*, Beata Roszkowska, Sylwester Czaplicki and Małgorzata Tańska \\ Chair of Food Plant Chemistry and Processing, Faculty of Food Sciences, University of Warmia and \\ Mazury in Olsztyn, Pl. Cieszyński 1, PL-10-726 Olsztyn, Poland \\ Received: January 27, 2016 \\ Accepted: July 29, 2016
}

\begin{abstract}
Summary
The study was carried out to optimize pumpkin oil recovery in the process of aqueous extraction preceded by enzymatic maceration of seeds, as well as to compare the quality of the obtained oil to the quality of cold-pressed pumpkin seed oil. Hydrated pulp of hulless pumpkin seeds was macerated using a $2 \%$ (by mass) cocktail of commercial pectinolytic, cellulolytic and proteolytic preparations (Rohapect ${ }^{\circledast}$ UF, Rohament ${ }^{\boxplus}$ CL and Colorase ${ }^{\oplus}$ 7089). The optimization procedure utilized response surface methodology based on Box-Behnken plan of experiment. The optimized variables of enzymatic pretreatment were $\mathrm{pH}$, temperature and maceration time. The results showed that the $\mathrm{pH}$ value, temperature and maceration time of $4.7,54{ }^{\circ} \mathrm{C}$ and $15.4 \mathrm{~h}$, respectively, were conducive to maximize the oil yield up to $72.64 \%$. Among these variables, the impact of $\mathrm{pH}$ was crucial (above $73 \%$ of determined variation) for oil recovery results. The oil obtained by aqueous enzymatic extraction was richer in sterols, squalene and tocopherols, and only slightly less abundant in carotenoids than the cold-pressed one. However, it had a lower oxidative stability, with induction period shortened by approx. $30 \%$ in relation to the cold-pressed oil.
\end{abstract}

Key words: enzymatic maceration, pumpkin oil, recovery optimization, induction period, phytochemicals

\section{Introduction}

Plant oil can be extracted by different methods, with prevailing techniques including non-polar solvent extraction or mechanical pressing (1). Processing conducted at low temperatures is recommended in the case of pharmaceutically valuable plant samples. The primary industrial method of bioactive oil production is pressing, usually done under the so-called cold conditions (2-4). This technique enables obtaining, for example, pumpkin oil rich in squalene, sterols and tocopherols (3), with a recommended 12-month period of shelf life (4). The limitation of this technology is, however, low oil recovery, which depends on the oil content in seeds and the press performances $(5,6)$.
The crucial step of oil extraction by any industrial process is disintegration of plant cell walls and oleosomes (7-9). Oleosomes $(10,11)$, which deposit lipids, are externally protected by the stable pectic and lignocellulose matrix of cell walls $(12,13)$. A study by Nikiforidis et al. (14) showed that the size of pores in the cell walls ranged from 20 to $80 \mathrm{~nm}$, and that they allowed the passage of components having a molecular mass of less than $9 \mathrm{kDa}$. To enable the release of larger cellular structures (such as most of oleosomes with diameters of $0.5-2 \mu \mathrm{m}$ ), the cells must be destroyed, which is most often achieved by mechanical processes. Campbell et al. (15) determined that efficient extraction of soybean oil was possible only after crushing the seeds to particles of less than $55 \mu \mathrm{m}$ (less than the 
length of a single cell). Such a high degree of cell disintegration is, however, difficult to achieve by physical treatment. Participation of pectic and cellulolytic enzymes may help in this process. The effective release of the lipid fraction may also be facilitated by degradation of oleosome proteins (14). These integral proteins cover the surface of oleosomes in the amount of approx. $3.2 \mathrm{mg} / \mathrm{m}^{2}$ and protect them against coalescence even under intense stress (e.g. centrifugation at $10000 \times g)$ and destructive chemicals (9 M urea or hexane) (15).

An aqueous enzymatic extraction may be an alternative in oil industry (1). Key advantages of this technique include: a relatively low cost of investment, still decreasing cost of commercial enzyme preparations, possibility of simultaneous isolation of unique, valuable plant chemicals (protein, phytochemicals, etc.), as well as meeting the general demand for the application of green technologies in the food industry $(16,17)$. Enzymatic pretreatment may be considered as a basic operation in aqueous extraction or as a preliminary stage before pressing or other kinds of extraction. However, the aqueous enzymatic extraction also has some disadvantages and limitations, e.g. the long processing time, the risk of hydrolysis and oxidation of compounds during extended process, relatively high cost of enzymes or preparations and the need for the rapid utilization of the unstable aqueous phase.

Different combinations of enzymes applied in aqueous extraction had been proposed for various plant samples. The tested mixtures were usually composed of pectinases, cellulases, hemicellulases, arabanase, $\beta$-glucanase and xylanase $(7-9,18-22)$. Additional enzymes such as proteinases, amylases, polygalacturonases and carboxymethyl cellulases were also utilized to enhance oil recovery from plant samples $(23,24)$. These enzymes had usually been used as mixtures, and the optimal effectiveness of oil recovery from plant samples was achieved with the use of approx. 1-3\% (by mass) of the enzyme preparation (or their cocktail). The optimum $\mathrm{pH}$ and temperature of enzymatic reactions ranged from 4 to 7.5 , and from 30 to $50^{\circ} \mathrm{C}$, respectively (20). The applied conditions enhanced enzyme activity and thus affected the physicochemical properties of plant compounds and plant matrix structure.

The previous studies of aqueous enzymatic extraction have not been carried out on pumpkin seeds. The main aim of this study is to optimize the temperature, $\mathrm{pH}$ and time of the enzymatic maceration of pumpkin seed using a cocktail of commercial enzyme preparations in order to maximize the pumpkin oil recovery. Response surface methodology was utilized to fit empirical data to a second-order polynomial model. An additional objective is to compare the quality and composition of the resultant oil to the oil produced by cold pressing.

\section{Materials and Methods}

\section{Materials}

The seeds of hulless pumpkin (Cucurbita pepo) cv. Herakles provided by Szarłat (Łomża, Poland) were utilized. The seeds were kept frozen at $(-18 \pm 2)^{\circ} \mathrm{C}$ until use.
Enzyme preparations were supplied by $\mathrm{AB}$ Enzymes $\mathrm{GmbH}$ (Darmstadt, Germany) and stored at $(6 \pm 2)^{\circ} \mathrm{C}$. Briefly, three different preparations were used: (i) Rohapect ${ }^{\circledR}$ UF, an enzyme preparation having pectinase and arabanase activity at an optimal $\mathrm{pH}=3.0-7.0$ and a temperature of 50-55 ${ }^{\circ} \mathrm{C}$, (ii) Rohament ${ }^{\oplus} \mathrm{CL}$, an enzyme preparation having cellulase, hemicellulase, celobiase and $\alpha$-glucanase activity at an optimal $\mathrm{pH}=4.0-4.5$ and a temperature of 60 ${ }^{\circ} \mathrm{C}$, and (iii) Colorase ${ }^{\circledR} 7089$, an enzyme preparation with protease activity at an optimal $\mathrm{pH}=5.0-5.5$ and $50-60^{\circ} \mathrm{C}$.

\section{Pumpkin seed pressing}

In the first stage of the study pressed reference oil was obtained from pumpkin seeds of Herakles cultivar with a moisture content of $9 \%$ on a Komet CA59G (IBG Monforts Oekotec GmbH \& Co.KG, Mönchengladbach, Germany) laboratory expeller (nozzle diameter of $5 \mathrm{~mm}$, shaft screw diameter of $33 \mathrm{~mm}$, rotation speed of $60 \mathrm{rpm}$ ) at a temperature of oil flowing from press cylinder not exceeding $50{ }^{\circ} \mathrm{C}$ (cold pressing). After obtaining the oil, it was centrifuged in an Eppendorf centrifuge (type 5810; Eppendorf AG, Hamburg, Germany) for $10 \mathrm{~min}$ at $24^{\circ} \mathrm{C}$ and a rotation speed of $11500 \times g$. Pressing procedure was conducted in three independent experiments and the results were expressed as the average values. Finally, the oil recovery was determined and expressed in percentage of the total oil content in seeds, estimated by Folch et al. (25) procedure. This method utilises chloroform/methanol mixture (2:1, by volume) for sample homogenization and is regarded as the most effective for the extraction of a broad range of lipid classes.

\section{Pumpkin seed enzymatic pretreatment}

In the second stage of the study fresh pumpkin seeds of Herakles cultivar were macerated using a cocktail of enzymes in an experiment planned according to the Box-Behnken model. The preliminary test (data not shown) specified the desired composition of the cocktail (single preparations or their mixtures) and minimum amount of the cocktail (containing equal mass of each preparation), which resulted in an efficiency of oil comparable to oil yield during cold pressing. The results of this stage indicated that all three enzymes should be added at a minimum mass fraction of $2 \%$. The process of enzymatic pretreatment started with the homogenization of $50 \mathrm{~g}$ of seeds with $50 \mathrm{~g}$ of water at room temperature using a hand blender (Braun, Frankfurt, Germany). The mixture was then adjusted to the desired $\mathrm{pH}$ with $0.1 \mathrm{M} \mathrm{HCl}$ and the required amount of enzyme cocktail was added. After this stage, the mixture was transferred to Erlenmeyer flasks and placed in a water bath (Elpan Water Bath Shaker type 357, Lubawa, Poland) at desired temperature. Following the required time of maceration, the sample was cooled to $24^{\circ} \mathrm{C}$ and centrifuged in 50-mL Falcon tubes at $24^{\circ} \mathrm{C}$ and $11500 \times g$ for $10 \mathrm{~min}$ in a type 5810 Eppendorf centrifuge (Eppendorf AG). The upper emulsion layer was gently isolated by siphoning using a micropipette. Residue in the tube was again centrifuged and the oil phase was withdrawn to obtain any residual oil. 


\section{Composition of oil bioactive compounds}

The composition of the main bioactive compounds and stability indices of the oil samples obtained by cold pressing and optimized aqueous enzymatic extraction were evaluated.

The content of sterols and squalene was determined by the GC/MS method as described by Roszkowska et al. (26), with modifications. The oil samples were dissolved in ethanol, and $5 \alpha$-cholestane (Sigma-Aldrich, Poznan, Poland) solution was added as an internal standard. The mixtures were saponified by adding $10 \mathrm{M} \mathrm{KOH}$ solution in methanol at $70^{\circ} \mathrm{C}$ for $30 \mathrm{~min}$, and then were transferred to a separatory funnel containing deionized water. Unsaponifiable fractions were extracted twice with diethyl ether. The ether layers were washed twice with $0.5 \mathrm{M}$ $\mathrm{KOH}$ and four times with deionized water, and evaporated in a vacuum evaporator at $45^{\circ} \mathrm{C}$. Pyridine and $\mathrm{N}, \mathrm{O}-$ -bis(trimethylsilyl) trifluoroacetamide (BSTFA) with $1 \%$ trimethylchlorosilane (TMCS; Sigma-Aldrich) were added to the dry extracts, and the mixtures were heated at 60 ${ }^{\circ} \mathrm{C}$ for $60 \mathrm{~min}$. Heptane was added after derivatization. The analysis was carried out using the GC-MS QP2010 PLUS (Shimadzu, Kyoto, Japan). Sterols were separated on a ZB-5MSi capillary column $(30 \mathrm{~m} \times 0.25 \mathrm{~mm} \times 0.25 \mu \mathrm{m}$; Phenomenex, Torrance, CA, USA), and with helium as a carrier gas at a flow rate of $0.9 \mathrm{~mL} / \mathrm{min}$. The temperatures were as follows: injector $230{ }^{\circ} \mathrm{C}$, column $70{ }^{\circ} \mathrm{C}$ increased to $230{ }^{\circ} \mathrm{C}$ at $15{ }^{\circ} \mathrm{C} / \mathrm{min}$, then to $310{ }^{\circ} \mathrm{C}$ at $3{ }^{\circ} \mathrm{C} / \mathrm{min}$, and maintained for $10 \mathrm{~min}$, GC-MS interface $240{ }^{\circ} \mathrm{C}$ and ion source $220^{\circ} \mathrm{C}$. Electron energy was set to $70 \mathrm{eV}$. The total ion current mode was used for quantification $(\mathrm{m} / \mathrm{z}=100$ $600)$. Sterols were identified by matching against the National Institute of Standards and Technology (NIST) MS spectral library (27), and their content was determined based on the concentration of the internal standard. The content of squalene was determined and quantified simultaneously with sterols.

The content of tocols in the oil samples was determined by HPLC, according to the method described by Czaplicki et al. (28). The oil was diluted in $n$-hexane and subsequently centrifuged ( $25000 \times g$ for $10 \mathrm{~min}$ ) in a type 5417R Eppendorf centrifuge (Eppendorf AG). The analysis was carried out using an Agilent Technologies 1200 RP-HPLC apparatus (Santa Clara, CA, USA), equipped with a fluorescent detector from the same manufacturer. Separation was performed on a LiChrospher Si60 column (250 mm $\times 4 \mathrm{~mm} \times 5 \mu \mathrm{m}$; Merck, Darmstadt, Germany). The mobile phase was a $0.7 \%$ isopropanol in $n$-hexane solution with a flow rate of $1 \mathrm{~mL} / \mathrm{min}$. The fluorescence detector was set at $\lambda_{\text {excitation }}=296 \mathrm{~nm}$ and $\lambda_{\text {emission }}=330 \mathrm{~nm}$. Tocols were quantified using standards of tocopherols (Merck). Their content was calculated using external calibration curves.

The content of carotenoids in the oil samples was analysed with a reversed-phase high-performance liquid chromatography (RP-HPLC) technique according to method described by Emenhiser et al. (29), modified by Konopka et al. (30). Briefly, oil samples with internal standard addition ( $\beta$-Apo- $8^{\prime}$-carotenal; Sigma-Aldrich) were saponified, extracted with hexane, and after organic solvent removal under a nitrogen stream, the residue was dis- solved in $2 \mathrm{~mL}$ of a methanol/dichloromethane (45:55, by volume) solution. The chromatographic analysis was carried out using a 1200 series liquid chromatograph (Agilent Technologies, Palo Alto, CA, USA), equipped with a diode array detector (DAD) from the same manufacturer. Separation was performed at $30{ }^{\circ} \mathrm{C}$ on a $\mathrm{YMC} \mathrm{C}_{30} 250$ $\mathrm{mm} \times 4.6 \mathrm{~mm}, 5 \mu \mathrm{m}$ column and $\mathrm{YMC} \mathrm{C}_{30} 10 \mathrm{~mm} \times 4.6 \mathrm{~mm}$, $3 \mu \mathrm{m}$ precolumn (YMC Europe GmbH, Dinslaken, Germany) using a methanol and methyl tert-butyl ether (MTBE) gradient procedure and diode array detection at $\lambda=450$ $\mathrm{nm}$. Carotenoids were identified based on retention times of available standards (Sigma-Aldrich), and by comparing the UV-Vis spectra.

\section{Oil recovery yield and other analyses}

Dry matter was determined according to AOAC method 925.10 (31). The total content of oil was determined according to Folch et al. (25) procedure. Oil recovery was computed as the ratio of the mass of recovered oil to the total oil content in the pumpkin seed. Oil $(2.5 \mathrm{~g})$ induction time was measured in the accelerated oxidation test at 110 ${ }^{\circ} \mathrm{C}$ with an air flow of $20 \mathrm{~L} / \mathrm{min}$ (32) using a Rancimat apparatus 743 (Methrom, Herisau, Switzerland). The acid and peroxide values were determined in accordance with EN ISO 660:2009 (33) and EN ISO 3960:2010 (34) procedures, respectively. Fatty acid composition of the obtained oil samples was determined according to Czaplicki et al. (35). Briefly, the fatty acids were methylated at $70{ }^{\circ} \mathrm{C}$ for $2 \mathrm{~h}$ with the use of chloroform/methanol/sulphuric acid (100:100:1, by volume) mixture. Separation of methyl esters was performed with the use of GC-MS QP2010 PLUS (Shimadzu) system on a BPX70 $(25 \mathrm{~m} \times 0.22 \mathrm{~mm} \times 0.25 \mu \mathrm{m})$ capillary column (SGE Analytical Science, Ringwood, Victoria, Australia) with helium as the carrier gas at a flow rate of $0.9 \mathrm{~mL} / \mathrm{min}$. The column temperature was programmed as follows: an increase from 150 to $180^{\circ} \mathrm{C}$ at the rate of $10^{\circ} \mathrm{C} / \mathrm{min}$, then to $185^{\circ} \mathrm{C}$ at the rate of $1.5^{\circ} \mathrm{C} / \mathrm{min}$, to $250{ }^{\circ} \mathrm{C}$ at the rate of $30^{\circ} \mathrm{C} / \mathrm{min}$, and then 10 -minute hold. The interface temperature of GC-MS was set at 240 ${ }^{\circ} \mathrm{C}$. The temperature of the ion source was $240^{\circ} \mathrm{C}$ and the electron energy $70 \mathrm{eV}$. The total ion current mode was used in $m / z=50-500$ range.

\section{Experimental design and statistical analysis}

A central composite design for the response surface methodology (RSM) was used to determine the optimum combination of temperature $\left(\mathrm{x}_{1}\right), \mathrm{pH}\left(\mathrm{x}_{2}\right)$ and time $\left(\mathrm{x}_{3}\right)$ allowed for the maximization of the oil yield $\left(\mathrm{y}_{1}\right)$. The experiment was conducted according to the Box-Behnken model with the variables at three variation levels, which resulted in 15 measuring points including the central point code $(0,0,0)$, repeated three times. The real values of experimental factors (Table 1 ) were selected for $\mathrm{pH}$ and temperature on the basis of the declaration of the producer of the enzyme preparations (values close to the optimum for all three preparations), and maceration time on the basis of preliminary studies in which maximum oil yield was obtained after approx. $12 \mathrm{~h}$ of enzymatic maceration. Real values assigned to the code $-1,0$ and +1 corresponded to the sequence from the lowest to average and to the highest factor level. 
Table 1. Coded and real values of experiment

\begin{tabular}{ccccc}
\hline & & -1 & 0 & 1 \\
\hline $\mathrm{x}_{1}$ & Temperature $/{ }^{\circ} \mathrm{C}$ & 45 & 50 & 55 \\
$\mathrm{x}_{2}$ & $\mathrm{pH}$ & 4.0 & 4.5 & 5.0 \\
$\mathrm{x}_{3}$ & $t / \mathrm{h}$ & 6 & 12 & 18 \\
\hline
\end{tabular}

The results of the experiments were used to develop the model of the oil recovery yield according to the second polynomial equation:

$$
\begin{gathered}
y=b_{0}+b_{1} x_{1}+b_{2} x_{2}+b_{3} x_{3}+b_{4} x_{1}^{2}+ \\
+b_{5} x_{2}^{2}+b_{6} x_{3}^{2}+b_{7} x_{1} x_{2}+b_{8} x_{1} x_{3}+b_{9} x_{2} x_{3}
\end{gathered}
$$

All statistical calculations were carried out at a significance level of $\mathrm{p}=0.05$ with STATISTICA v. 12.5 (StatSoft, Inc., Kraków, Poland) software.

\section{Results and Discussion}

\section{Oil recovery optimization}

Pumpkin seeds of Herakles cultivar contained on dry mass basis $49.62 \%$ of oil. The cold-pressed oil yield on dry mass basis was $33.48 \%$, corresponding to $67.47 \%$ of its recovery from the pumpkin seeds (oil content of resulting press cake was $24.23 \%$ ). The pumpkin oil yield values after the enzymatic maceration are shown in Table 2 , while the equation representing the empirical relationships of this feature to independent coded variables (temperature $\left(\mathrm{x}_{1}\right), \mathrm{pH}\left(\mathrm{x}_{2}\right)$ and time $\left.\left(\mathrm{x}_{3}\right)\right)$ is as follows:

$$
\begin{aligned}
& \mathrm{y}_{1}= 55.610+6.615 \mathrm{x}_{1}+20.030 \mathrm{x}_{2}+7.698 \mathrm{x}_{3}+ \\
&+3.594 \mathrm{x}_{1}^{2}+14.517 \mathrm{x}_{2}^{2}+5.929 \mathrm{x}_{3}^{2}+6.495 \mathrm{x}_{1} \mathrm{x}_{2}+ \\
&+3.105 \mathrm{x}_{1} \mathrm{x}_{3}+6.212 \mathrm{x}_{2} \mathrm{x}_{3}\left(\mathrm{R}^{2}=0.92\right)
\end{aligned}
$$

The $\mathrm{p}$ and $\mathrm{t}$ values for each regression coefficient are presented in Table 3 . The results of the analysis of variance (Table 4) showed that the maceration $\mathrm{pH}$ had a significant and decisive impact on the oil yield (above $73 \%$ of the total variation including the linear and quadratic effects). The highest oil recovery, equal to $72.6 \%$, was obtained at the optimized conditions: temperature $=54{ }^{\circ} \mathrm{C}$, $\mathrm{pH}=4.7$ and $t=15.4 \mathrm{~h}$ (Fig. 1).

The determined parameters of oil recovery maximization may stimulate both the activity of the added and native enzymes as well as the physical and chemical changes in cell components. This was confirmed by the results obtained for the samples processed without the addition of enzyme cocktail, in which spontaneous release of the oil in the mass fraction of approx. $32 \%$ was noted (Table 2). A factor that facilitates the aqueous extraction of hydrophobic compounds is the hydration, which increases the differences in the hydrophobic interactions (van der Waals forces) and hydrophilic (hydrogen and ionic bonding) components of the matrix (7). This process increases intracellular pressure, which may lead to the destruction of cell walls and membranes (7), which facilitates oil release. The release of lipids from plant pulp is highly dependent on temperature, which affects pro-

\begin{tabular}{|c|c|c|c|c|c|}
\hline \multirow{2}{*}{ No. } & \multirow{2}{*}{$\frac{\text { Temp. }}{{ }^{\circ} \mathrm{C}}$} & \multirow{2}{*}{$\mathrm{pH}$} & \multirow{2}{*}{$\frac{t \text { (maceration) }}{\mathrm{h}}$} & \multicolumn{2}{|c|}{ Oil recovery/\% } \\
\hline & & & & Experimental & Predicted \\
\hline 1 & -1.0 & -1.0 & 0.0 & $43.33 \pm 0.67$ & 43.45 \\
\hline 2 & 1.0 & -1.0 & 0.0 & $40.87 \pm 0.79$ & 43.57 \\
\hline 3 & -1.0 & 1.0 & 0.0 & $59.69 \pm 0.45$ & 56.99 \\
\hline 4 & 1.0 & 1.0 & 0.0 & $70.21 \pm 0.72$ & 70.10 \\
\hline 5 & -1.0 & 0.0 & -1.0 & $59.25 \pm 0.65$ & 56.51 \\
\hline 6 & 1.0 & 0.0 & -1.0 & $65.34 \pm 1.06$ & 60.02 \\
\hline 7 & -1.0 & 0.0 & 1.0 & $55.78 \pm 0.99$ & 61.10 \\
\hline 8 & 1.0 & 0.0 & 1.0 & $68.08 \pm 0.88$ & 70.82 \\
\hline 9 & 0.0 & -1.0 & -1.0 & $37.81 \pm 0.32$ & 40.43 \\
\hline 10 & 0.0 & 1.0 & -1.0 & $48.81 \pm 0.97$ & 54.26 \\
\hline 11 & 0.0 & -1.0 & 1.0 & $47.36 \pm 0.85$ & 41.92 \\
\hline 12 & 0.0 & 1.0 & 1.0 & $70.78 \pm 0.63$ & 68.16 \\
\hline 13 & 0.0 & 0.0 & 0.0 & $71.46 \pm 1.00$ & 71.64 \\
\hline 14 & 0.0 & 0.0 & 0.0 & $72.91 \pm 0.96$ & 71.64 \\
\hline 15 & 0.0 & 0.0 & 0.0 & $70.54 \pm 0.97$ & 71.64 \\
\hline $16^{\mathrm{a}}$ & 0.8046 & 0.4948 & 0.5596 & $31.78 \pm 0.35$ & - \\
\hline $16^{\mathrm{b}}$ & 0.8046 & 0.4948 & 0.5596 & $72.64 \pm 0.61$ & 76.52 \\
\hline
\end{tabular}
tein denaturation and viscosity of the oil phase. Increasing the temperature usually facilitates oil release from the
Table 2. Results of three-factorial optimization procedure based on Box-Behnken model

Experimental results are mean value \pm standard deviation (S.D.),

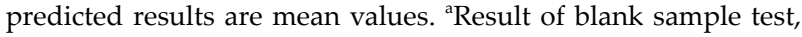
which was conducted to determine optimal maceration conditions without the addition of enzymatic cocktail (spontaneous oil release), 'result of sample test, which was conducted to determine optimal maceration conditions with the addition of enzymatic cocktail

cell. Previous research showed that the optimal temperature of soybean seed oil release was below $50{ }^{\circ} \mathrm{C}$, while in the case of peanuts close to $60-64{ }^{\circ} \mathrm{C}(14)$. Also, $\mathrm{pH}$ modification can influence both the destabilization of the membrane components (oleosome aggregation at the isoelectric point) and change of the electrical state of other

Table 3. Significance of coefficients used in regression equations

\begin{tabular}{lccc}
\hline Variable & $\begin{array}{c}\text { Regression } \\
\text { coefficient }\end{array}$ & $\begin{array}{c}\text { Computed } \\
t \text {-value }\end{array}$ & p-value \\
\hline Constant & 55.610 & 87.712 & 0.00000 \\
Linear & & 4.260 & 0.00015 \\
$\mathrm{x}_{1}$ & 6.615 & 12.897 & 0.00000 \\
$\mathrm{x}_{2}$ & 20.030 & 4.957 & 0.00002 \\
$\mathrm{x}_{3}$ & 7.698 & & \\
Quadratic & & 3.144 & 0.00339 \\
$\mathrm{x}_{1}{ }^{2}$ & 3.594 & 12.701 & 0.00000 \\
$\mathrm{x}_{2}{ }^{2}$ & 14.517 & 5.187 & 0.00001 \\
$\mathrm{x}_{3}{ }^{2}$ & 5.929 & & \\
Interaction & & 2.957 & 0.00553 \\
$\mathrm{x}_{1} \cdot \mathrm{x}_{2}$ & 6.495 & 1.414 & 0.16627 \\
$\mathrm{x}_{1} \cdot \mathrm{x}_{3}$ & 3.105 & 2.829 & 0.00769 \\
$\mathrm{x}_{2} \cdot \mathrm{x}_{3}$ & 6.212 & & \\
\hline
\end{tabular}

$\mathrm{x}_{1}$ =temperature, $\mathrm{x}_{2}=\mathrm{pH}, \mathrm{x}_{3}=$ time 
Table 4. Results of variance analysis of oil recovery

\begin{tabular}{lrrrrc}
\hline $\begin{array}{l}\text { Impact } \\
\text { of effect }\end{array}$ & \multicolumn{1}{c}{ SS } & DF & \multicolumn{1}{c}{ MS } & \multicolumn{1}{c}{$\mathrm{F}$} & $\mathrm{p}$ \\
\hline $\mathrm{x}_{1}(\mathrm{~L}+\mathrm{Q})$ & 405.622 & 2 & 202.811 & 14.015 & 0.00003 \\
$\mathrm{x}_{2}(\mathrm{~L}+\mathrm{Q})$ & 4741.486 & 2 & 2370.743 & 163.829 & 0.00000 \\
$\mathrm{x}_{3}(\mathrm{~L}+\mathrm{Q})$ & 744.888 & 2 & 372.444 & 25.738 & 0.00000 \\
$\mathrm{x}_{1} \cdot \mathrm{x}_{2}$ & 126.555 & 1 & 126.555 & 8.745 & 0.00553 \\
$\mathrm{x}_{1} \cdot \mathrm{x}_{3}$ & 28.923 & 1 & 28.923 & 1.999 & 0.16627 \\
$\mathrm{x}_{2} \cdot \mathrm{x}_{3}$ & 115.779 & 1 & 115.779 & 8.001 & 0.00769 \\
Error & 506.479 & 35 & 14.471 & & \\
Total SS & 6446.314 & 44 & & & \\
\hline
\end{tabular}

$\mathrm{x}_{1}=$ temperature, $\mathrm{x}_{2}=\mathrm{pH}, \mathrm{x}_{3}=$ time, $\mathrm{L}=$ linear effect, $\mathrm{Q}=$ quadratic effect, $\mathrm{SS}=$ sum of squares, $\mathrm{DF}=$ degree of freedom, MS=mean square value
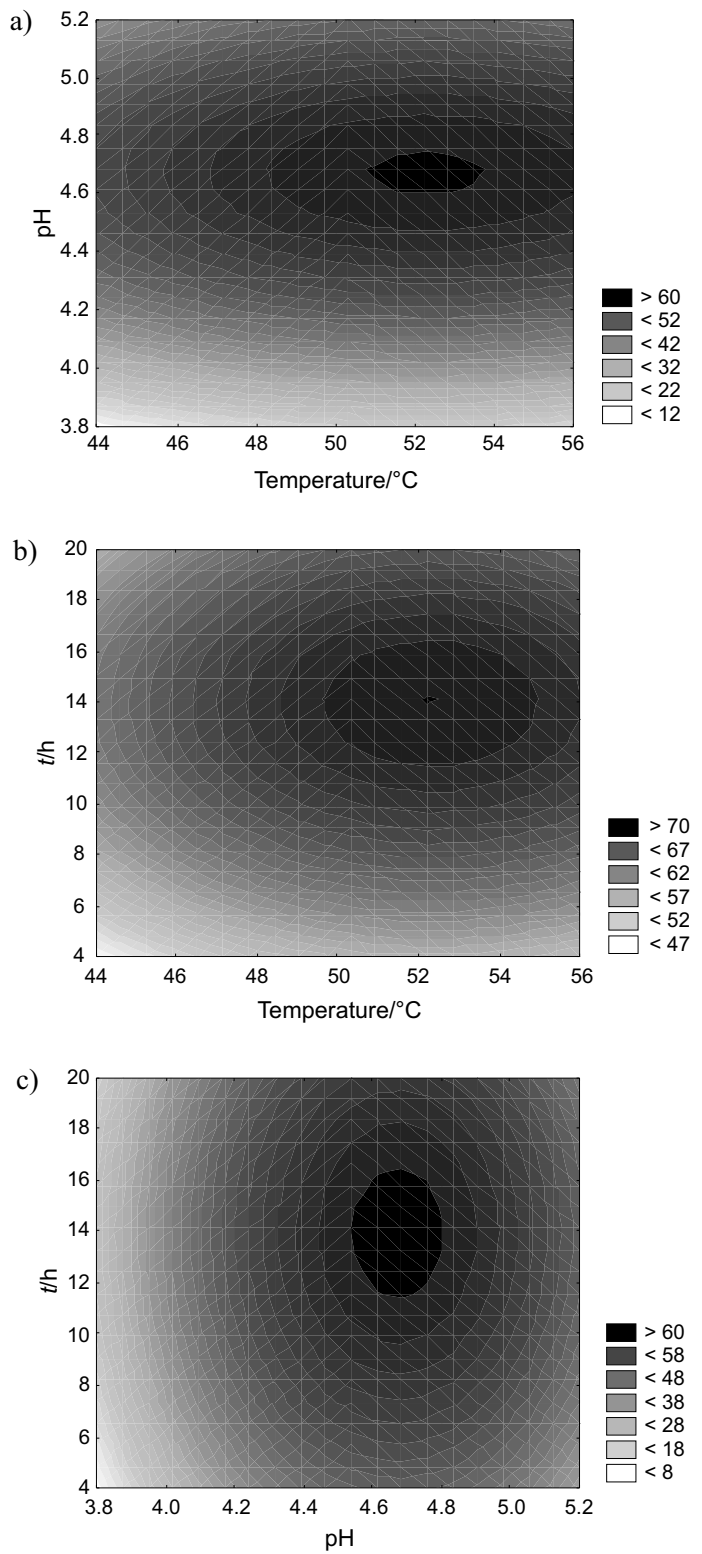

Fig. 1. 2D contour plots of the oil recovery affected by enzymatic maceration: a) $\mathrm{pH}$ and temperature, b) time and temperature, and c) time and $\mathrm{pH}$ chemical components of the cell. However, experimental data on the choice of $\mathrm{pH}$ conducive to releasing the oil phase are ambiguous. For example, for maize seeds the $\mathrm{pH}$ value should be close to 6 (the isoelectric point of oleosomes) or 9 (14). In the latter case, the breakdown of oleosomes had the character of chemical hydrolysis, which may destroy the essential amino acids and thus reduce the biological value of the defatted vegetable matrix.

The results confirmed that the cell wall- and oleosome-degrading enzymes may be utilized as an essential step in aqueous extraction or as a pretreatment step followed by pressing or other extraction techniques. However, the net effect of enzymatic, physical and chemical processes during enzymatic maceration is difficult to predict, and requires empirical verification with respect to specific raw material (e.g. seeds) and types of applied preparations. The previously conducted research showed that the application of $3 \%$ (by volume per mass) of commercial preparations of pectinases, cellulases, hemicellulases, arabanase, $\beta$-glucanase and xylanase resulted in approx. 55-60 \% recovery of soya oleosomes (14). Optimized conditions of grapefruit seed pretreatment with an enzyme cocktail consisting of cellulase, protease, xylanase and pectinase $(29,1191,21$ and $569 \mathrm{U}$ per $\mathrm{g}$ of seed, respectively) increased by approx. $106 \%$ the yield of the oil subsequently extracted by hexane (20). Similarly, the enzyme cocktail (cellulase, pectinase and proteinase), assisted by microwave treatment, allowed an approx. 2-fold increase in the yield of pumpkin oil extracted by hexane (21). Optimum conditions of the seed enzymatic pretreatment were: $1.4 \%$ (by mass) of enzymes (in equal mass proportions), and temperature of $44{ }^{\circ} \mathrm{C}$. Multienzyme preparations (protease Neutrase 0.8L, $\alpha$-amylase Termamyl 120L, cellulase Celluclast 1.5L FG and pectinase Pectinex Ultra SP-L) have been used to enhance the effectiveness of the isolation of oil from Moringa oleifera seed (24). The highest oil recovery (approx. $74 \%$ ) was obtained by an enzyme dose of $2 \%$ (by mass), when the process was followed at $\mathrm{pH}=7.5$ and $45{ }^{\circ} \mathrm{C}$ and with additional agitation (approx. $120 \mathrm{rpm}$ ) (24). Li et al. (36) optimized the aqueous multienzyme (cellulase, pentosanase, neutrase and amylase) extraction of wheat germ oil and found that the optimal set of variables was $\mathrm{pH}=5.24$, temperature of $48.49^{\circ} \mathrm{C}$, time of $6 \mathrm{~h}$ and water to wheat germ ratio of $3.46 \mathrm{~mL} / \mathrm{g}$. Increased recovery of oil after enzymatic maceration was also determined for olive seeds with the use of a Cytolase preparation (pectinase, cellulase and hemicellulase) (22) and for pequi fruit with the use of polygalacturonase and carboxymethyl cellulase (23). A simplified economic calculation estimated costs of the proposed technology at approx. 0.15 euro or dollar per $\mathrm{kg}$ of dry matter of pumpkin seed or approx. 0.45 euro or dollar per $\mathrm{kg}$ of obtained oil. In Poland, it constitutes approx. $10 \%$ of the market price of pumpkin oil.

\section{Pumpkin oil quality in relation to extraction procedure}

Comparison of cold-pressed and aqueously extracted oil samples showed significant differences of tocopherols, carotenoids, sterols and squalene contents (Table 5). Sterols (approx. $53 \%$ of total phytochemicals) and squalene (approx. $28 \%$ ) prevailed in both oil types. The aqueously 
Table 5. Characteristics of pumpkin oil obtained with different extraction procedures

\begin{tabular}{|c|c|c|}
\hline Compound & $\begin{array}{c}\text { Cold } \\
\text { pressing }\end{array}$ & $\begin{array}{l}\text { Aqueous } \\
\text { enzymatic } \\
\text { extraction }\end{array}$ \\
\hline Oil recovery/\% & $(67.4 \pm 1.7)^{\mathrm{b}}$ & $(72.6 \pm 1.1)^{\mathrm{a}}$ \\
\hline Acid value/(mg of $\mathrm{KOH}$ per $\mathrm{g}$ ) & $(1.4 \pm 0.4)^{\mathrm{b}}$ & $(4.9 \pm 0.5)^{\mathrm{a}}$ \\
\hline Peroxide value/(meq of $\mathrm{O}_{2}$ per kg) & $(1.2 \pm 0.1)^{\mathrm{b}}$ & $(1.8 \pm 0.2)^{\mathrm{a}}$ \\
\hline \multirow[t]{2}{*}{$t$ (induction) $/ \mathrm{h}$} & $(9.4 \pm 0.5)^{\mathrm{a}}$ & $(6.6 \pm 0.3)^{b}$ \\
\hline & \multicolumn{2}{|c|}{$w /(\mathrm{mg} / 100 \mathrm{~g}$ oil $)$} \\
\hline Tocopherols & $(44.5 \pm 0.7)^{b}$ & $(55.3 \pm 0.4)^{\mathrm{a}}$ \\
\hline$\alpha$-tocopherol & $(13.0 \pm 0.2)^{\mathrm{b}}$ & $(16.23 \pm 0.06)^{a}$ \\
\hline$\beta$-tocopherol & $(2.23 \pm 0.09)^{\mathrm{b}}$ & $(2.61 \pm 0.02)^{a}$ \\
\hline$\gamma$-tocopherol & $(29.3 \pm 0.7)^{\mathrm{b}}$ & $(36.5 \pm 0.4)^{c}$ \\
\hline Carotenoids & $(22.8 \pm 0.6)^{\mathrm{a}}$ & $(21.0 \pm 0.9)^{\mathrm{a}}$ \\
\hline Lutein & $(8.8 \pm 0.1)^{\mathrm{a}}$ & $(6.3 \pm 0.1)^{b}$ \\
\hline$\alpha$-carotene & $(1.70 \pm 0.03)^{\mathrm{b}}$ & $(2.3 \pm 0.7)^{\mathrm{a}}$ \\
\hline$\gamma$-carotene & $(5.8 \pm 0.2)^{\mathrm{a}}$ & $(5.9 \pm 0.2)^{\mathrm{a}}$ \\
\hline 9-cis- $\gamma$-carotene & $(1.88 \pm 0.04)^{\mathrm{a}}$ & $(1.96 \pm 0.09)^{\mathrm{a}}$ \\
\hline Unidentified & $(4.6 \pm 0.1)^{\mathrm{a}}$ & $(4.58 \pm 0.06)^{\mathrm{a}}$ \\
\hline Sterols & $(180.6 \pm 0.3)^{\mathrm{b}}$ & $(217.9 \pm 1.1)^{\mathrm{a}}$ \\
\hline Campesterol & $(16.59 \pm 0.03)^{\mathrm{b}}$ & $(5.51 \pm 0.01)^{\mathrm{b}}$ \\
\hline Stigmasterol & $(2.38 \pm 0.04)^{\mathrm{a}}$ & $(1.49 \pm 0.03)^{b}$ \\
\hline Spinasterol and $\gamma$-sitosterol & $(90.0 \pm 0.3)^{b}$ & $(105.3 \pm 0.4)^{\mathrm{a}}$ \\
\hline$\Delta 7,22,25$-stigmastatrienol & $(27.4 \pm 0.3)^{\mathrm{b}}$ & $(43.0 \pm 0.0)^{\mathrm{a}}$ \\
\hline$\Delta 7$-stigmastenol & $(12.0 \pm 0.3)^{\mathrm{b}}$ & $(17.1 \pm 0.1)^{\mathrm{a}}$ \\
\hline$\Delta 7,25$-stigmastadienol & $(26.44 \pm 0.02)^{\mathrm{b}}$ & $(39.6 \pm 0.3)^{\mathrm{a}}$ \\
\hline$\Delta 7$-avenasterol & $(5.7 \pm 0.2)^{\mathrm{a}}$ & $(5.88 \pm 0.05)^{\mathrm{a}}$ \\
\hline Squalene & $(95.23 \pm 0.5)^{\mathrm{b}}$ & $(115.9 \pm 0.9)^{\mathrm{a}}$ \\
\hline Total phytochemicals & $(343.2 \pm 0.5)^{\mathrm{b}}$ & $(410.1 \pm 1.0)^{\mathrm{a}}$ \\
\hline Fatty acids & \multicolumn{2}{|c|}{$w / \%$} \\
\hline Palmitic (C16:0) & $(12.5 \pm 0.2)^{\mathrm{b}}$ & $(14.0 \pm 0.2)^{a}$ \\
\hline Stearic (C18:0) & $(4.6 \pm 0.2)^{\mathrm{a}}$ & $(5.03 \pm 0.08)^{\mathrm{a}}$ \\
\hline Oleic (C18:1) & $(28.6 \pm 1.9)^{\mathrm{a}}$ & $(24.6 \pm 1.3)^{\mathrm{b}}$ \\
\hline Linoleic (C18:2) & $(52.8 \pm 1.2)^{\mathrm{b}}$ & $(55.8 \pm 1.7)^{\mathrm{a}}$ \\
\hline Linolenic (C18:3) & $(1.0 \pm 0.4)^{\mathrm{a}}$ & $(0.3 \pm 0.2)^{\mathrm{a}}$ \\
\hline Others & $(0.6 \pm 0.2)^{a}$ & $(0.37 \pm 0.06)^{a}$ \\
\hline
\end{tabular}

All results are mean value \pm standard deviation (S.D.). Mean values with the same letter in a row did not differ significantly $(\mathrm{p} \leq 0.05)$

extracted oil was more abundant in tocopherols (by $24 \%$ ), sterols (by $21 \%$ ) and squalene (by $22 \%$ ), and only slightly less abundant in carotenoids (by $8 \%$ ). In summary, aqueously extracted oil contained $410.1 \mathrm{mg}$ of phytochemicals per $100 \mathrm{~g}$, while cold-pressed contained only $343.2 \mathrm{mg}$ per $100 \mathrm{~g}$ of oil. In contrast, the fatty acid composition of both oil types differed only slightly, where linoleic (approx. $53-56 \%$ ), oleic (approx. 25-29\%) and palmitic (approx. 13-14 \%) acids were found to prevail. The determined composition of pumpkin oil was close to that cited in the earlier works $(3,37-42)$ with typical variation due to genotype and cropping conditions $(38,43)$.
In both oil types, irrespective of the extraction method, the fraction of tocopherols was composed of approx. $2 / 3$ of the $\gamma$-homologue, with constant shares of $\alpha$ - and $\gamma$-homologues of 29 and $5 \%$, respectively. The major carotenoid isomers were lutein and $\beta$-carotene (Fig. 2), with contents varying from 30.1 to $38.7 \%$ (lutein), and from 25.3 to $28.1 \%$ ( $\beta$-carotene) depending on the extraction method. Additionally, 9 -cis- $\beta$-carotene, $\alpha$-carotene and traces of zeaxanthin were identified. Among sterols, spinasterol and $\beta$-sitosterol predominated (Fig. 3 ), which accounted for approx. $50 \%$ in total. Apart from them, analyses revealed the presence of campesterol, stigmasterol, $\Delta 7,22,25$-stigmastatrienol and some homologues of $\Delta 7$ -sterols. The determined sterol composition was similar to that reported by Srbinoska et al. (40) and Hrabovski et al. (41), who showed that $\Delta 7$-sterols were predominant in pumpkin oil. In turn, Ryan et al. (42) found that pumpkin oil sterols were composed almost exclusively of $\beta$-sitosterol (approx. $75 \%$ of total). Aqueous extraction significantly affected oil sterols, with the highest increase of spinasterol with $\gamma$-sitosterol, $\Delta 7,22,25$-stigmastatrienol and $\Delta 7,25$-stigmastadienol contents, and a major decrease of campesterol content.

A comparison of acid and peroxide values and induction period showed significant differences between the oil

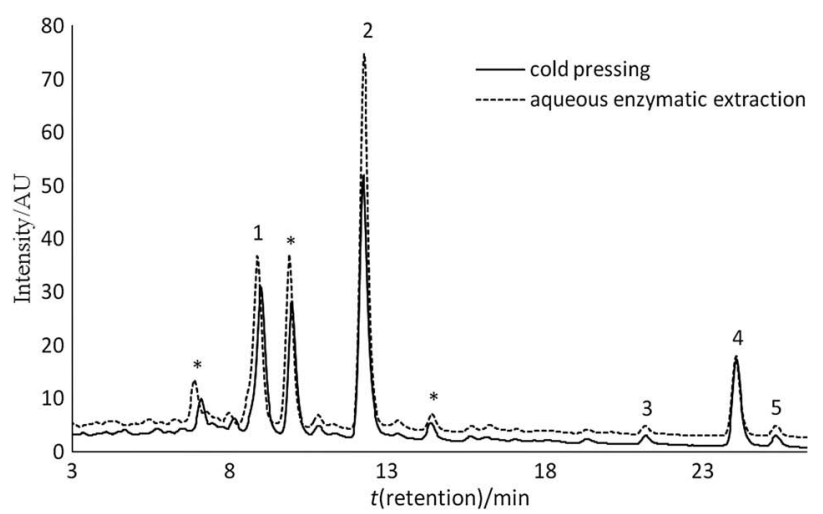

Fig. 2. Chromatogram of carotenoid fraction in pumpkin oil. $1=$ lutein, $2=\beta$-apo- $8^{\prime}$-carotenal (internal standard), $3=\alpha$-carotene, $4=\beta$-carotene, $5=9$-cis- $\beta$-carotene, ${ }^{*}$ unidentified

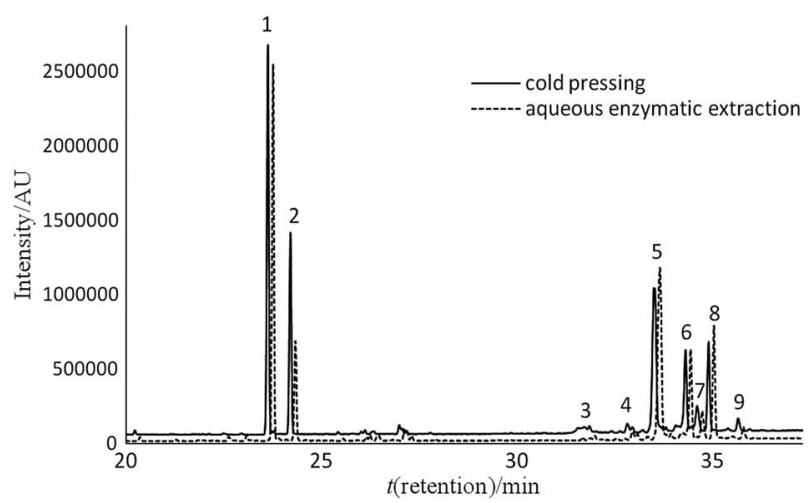

Fig. 3. Chromatogram of sterol fraction in pumpkin oil. 1=squalene, $2=5 \alpha$-cholestane (internal standard), 3=campesterol, $4=$ stigmasterol, $5=$ spinasterol and $\beta$-sitosterol, $6=\Delta 7,22,25$-stigmastatrienol, $7=\Delta 7$-stigmastenol, $8=\Delta 7,25$-stigmastadienol, $9=\Delta 7$-avenasterol 
samples (Table 5). The aqueously extracted oil contained more free fatty acids and primary products of oxidation than the cold-pressed oil (4.9 vs. $1.4 \mathrm{mg}$ of $\mathrm{KOH}$ per $\mathrm{g}$, and 1.8 vs. 1.0 meq of $\mathrm{O}_{2}$ per $\mathrm{kg}$, respectively). The main reason for high acid number was probably prolonged activity of native seed enzymes, especially lipases, since the optimum temperature and $\mathrm{pH}$ for lipases of various origin ranges between 30 and $80{ }^{\circ} \mathrm{C}$, and between 4.5 and 11, respectively (44). It seems that variation of these parameters affected mostly oil oxidative stability. Although aqueously extracted oil was characterized by a higher concentration of soluble antioxidants, its induction period equalled to $6.55 \mathrm{~h}$, which was by approx. $30 \%$ shorter than of the cold-pressed oil $(9.38 \mathrm{~h})$. Although induction period of the aqueously extracted oil was relatively short, it was similar to that determined for other pumpkin oil types (45). Additional experiments done in our laboratory (data not shown) showed that the acid value up to $4 \mathrm{mg}$ of $\mathrm{KOH}$ per $\mathrm{g}$, recommended by Codex Alimentarius Commission (46) for cold-pressed and virgin oil, may be achieved with the use of pumpkin seeds of initial acid value up to $1 \mathrm{mg}$ of $\mathrm{KOH}$ per $\mathrm{g}$ or with their thermal pretreatment.

\section{Conclusions}

The use of $2 \%$ (by mass) of enzyme cocktail (Rohapect ${ }^{\circledast}$ UF, Rohament ${ }^{\circledast}$ CL and Colorase ${ }^{\circledast} 7089$ in equal mass proportions) resulted in the extraction of $36.0 \%$ (on dry seed matter basis) of pumpkin oil $(72.6 \%$ of total available lipids). The highest oil yield was achieved under process conditions of temperature $=54{ }^{\circ} \mathrm{C}, \mathrm{pH}=4.7$ and $t=15.4 \mathrm{~h}$. Optimized variables of oil recovery yield were mostly related to pulp maceration $\mathrm{pH}$. A comparison of the extraction procedures showed that oil extracted by the aqueous enzymatic extraction was more abundant in sterols, tocopherols and squalene, but its oxidative stability was significantly reduced. The proposed technology of seed pretreatment with the use of a cocktail of commercial pectinolytic, cellulolytic and proteolytic preparations is a good alternative to the industrial process of cold pressing of pharmaceutically valuable seeds.

\section{References}

1. Ahmadi M, Zahedi G, Karimi F. Application of the response surface methodology for the optimization of the aqueous enzymatic extraction of pistacia khinjuk oil. J Food Biosci Technol. 2013;3:1-10.

2. Radočaj O, Dimić E, Vujasinović V. Development of a hull-less pumpkin (Cucurbita pepo L.) seed oil press-cake spread. J Food Sci. 2012;77:C1011-7. http://dx.doi.org/10.1111/j.1750-3841.2012.02874.x

3. Rabrenović BB, Dimić EB, Novaković MM, Tešević VV, Basić $\mathrm{ZN}$. The most important bioactive components of cold pressed oil from different pumpkin (Cucurbita pepo L.) seeds. LWT - Food Sci Technol. 2014;55:521-7. http://dx.doi.org/10.1016/j.lwt.2013.10.019

4. Vujasinovic V, Djilas S, Dimic E, Romanic R, Takaci A. Shelf life of cold-pressed pumpkin (Cucurbita pepo L.) seed oil obtained with a screw press. J Am Oil Chem Soc. 2010;87: 1497-505. http://dx.doi.org/10.1007/s11746-010-1630-x

5. Dimić E. Cold-pressed oils. Monograph, Novi Sad, Serbia: Faculty of Technology, University of Novi Sad; 2005. pp. 1-230 (in Serbian).
6. Zhao X, Wei L, Julson J, Huang Y. Investigated cold press oil extraction from non-edible oilseeds for future bio-jet fuels production. JSBS. 2014;4:199-214.

http://dx.doi.org/10.4236/jsbs.2014.44019

7. Mustafa A, Turner C. Pressurized liquid extraction as a green approach in food and herbal plants extraction: a review. Anal Chim Acta. 2011;703:8-18. http://dx.doi.org/10.1016/j.aca.2011.07.018

8. Waldron KW, Parker ML, Smith AC. Plant cell walls and food quality. Compr Rev Food Sci Food Saf. 2003;2:128-46. http://dx.doi.org/10.1111/j.1541-4337.2003.tb00019.x

9. Wang L, Weller CL. Recent advances in extraction of nutraceuticals from plants. Trends Food Sci Tech. 2006;17:300-12. http://dx.doi.org/10.1016/j.tifs.2005.12.004

10. Iwanaga D, Gray DA, Fisk ID, Decker EA, Weiss J, McClements DJ. Extraction and characterization of oil bodies from soy beans: a natural source of pre-emulsified soybean oil. J Agric Food Chem. 2007;55:8711-6. http://dx.doi.org/10.1021/jf071008w

11. Tzen JTC, Cao YZ, Laurent P, Ratnayake C, Huang AHC. Lipids, proteins, and structure of seed oil bodies from diverse species. Plant Physiol. 1993;101:267-76.

12. Cosgrove DJ. Growth of the plant cell wall. Nat Rev Mol Cell Biol. 2005;6:850-61. http://dx.doi.org/10.1038/nrm1746

13. Pérez J, Muñoz-Dorado J, de la Rubia T, Martínez J. Biodegradation and biological treatments of cellulose, hemicelluloses and lignin: an overview. Int Microbiol. 2002;5:53-63. http://dx.doi.org/10.1007/s10123-002-0062-3

14. Nikiforidis CV, Kiosseoglou V, Scholten E. Oil bodies: an insight on their microstructure - maize germ vs sunflower seed. Food Res Int. 2013;52:136-41.

http://dx.doi.org/10.1016/j.foodres.2013.02.052

15. Campbell KA, Glatz CE, Johnson LA, Jung S, de Moura JMN, Kapchie V, Murpy P. Advances in aqueous extraction processing of soybeans. J Am Oil Chem Soc. 2011;88:449-65. http://dx.doi.org/10.1007/s11746-010-1724-5

16. Klein-Marcuschamer D, Oleskowicz-Popiel P, Simmons BA, Blanch HW. The challenge of enzyme cost in the production of lignocellulosic biofuels. Biotechnol Bioeng. 2012;109:1083-7. http://dx.doi.org/10.1002/bit.24370

17. Salgin U, Korkmaz H. A green separation process for recovery of healthy oil from pumpkin seed. J Supercrit Fluids. 2011;58:239-48. http://dx.doi.org/10.1016/j.supflu.2011.06.002

18. Puri M, Sharma D, Barrow CJ. Enzyme-assisted extraction of bioactives from plants. Trends Biotechnol. 2012;30:37-44. http://dx.doi.org/10.1016/j.tibtech.2011.06.014

19. Kapchie VN, Towa LT, Hauck C, Murphy PA. Evaluation of enzyme efficiency for soy oleosome isolation and ultrastructural aspects. Food Res Int. 2010;43:241-7. http://dx.doi.org/10.1016/j.foodres.2009.09.019

20. Passos CP, Yilmaz S, Silva CM, Coimbra MA. Enhancement of grape seed oil extraction using a cell wall degrading enzyme cocktail. Food Chem. 2009;115:48-53. http://dx.doi.org/10.1016/j.foodchem.2008.11.064

21. Jiao J, Li ZG, Gai QY, Li XJ, Wei FY, Fu YJ, Ma W. Microwaveassisted aqueous enzymatic extraction of oil from pumpkin seeds and evaluation of its physicochemical properties, fatty acid compositions and antioxidant activities. Food Chem. 2014;147:17-24. http://dx.doi.org/10.1016/j.foodchem.2013.09.079

22. Bhat MK. Cellulases and related enzymes in biotechnology. Biotechnol Adv. 2000;18:355-83. http://dx.doi.org/10.1016/S0734-9750(00)00041-0

23. Gomes de Brito Mariano R, Couri S, Freitas SP. Enzymatic technology to improve oil extraction from Caryocar brasil- 
iense Camb (Pequi) pulp. Rev Bras Frutic. 2009;31:637-43. http://dx.doi.org/10.1590/S0100-29452009000300003

24. Abdulkarim SM, Lai OM, Muhammad SKS, Long K, Ghazali HM. Use of enzymes to enhance oil recovery during aqueous extraction of Moringa oleifera seed oil. J Food Lipids. 2006;13:113-30.

http://dx.doi.org/10.1111/j.1745-4522.2006.00038.x

25. Folch J, Lees M, Stanley GHS. A simple method for the isolation and purification of total lipides from animal tissues. J Biol Chem. 1957;226:497-509.

26. Roszkowska B, Tańska M, Czaplicki S, Konopka I. Variation in the composition and oxidative stability of commercial rapeseed oils during their shelf life. Eur J Lipid Sci Technol. 2015;117:673-83. http://dx.doi.org/10.1002/ejlt.201400271

27. NIST Mass Spectral Library, NIST. Gaithersburg, MD, USA: National Institute of Standards and Technology; 2008. Available from: https://www.nist.gov/srd.

28. Czaplicki S, Ogrodowska D, Derewiaka D, Tańska M, Zadernowski R. Bioactive compounds in unsaponifiable fraction of oils from unconventional sources. Eur J Lipid Sci Tech. 2011;113:1456-64. http://dx.doi.org/10.1002/ejlt.201000410

29. Emenhiser C, Sander LC, Schwartz SJ. Capability of apolimeric $C_{30}$ stationary phase to resolve cis-trans carotenoid isomers in reverse-phase liquid chromatography. J Chromatogr A. 1995;707:205-16. http://dx.doi.org/10.1016/0021-9673(95)00336-L

30. Konopka I, Tańska M, Faron A, Stępień A, Wojtkowiak K. Comparison of the phenolic compounds, carotenoids and tocochromanols content in wheat grain from organic and mineral fertilization. Molecules. 2012;17:12341-56. http://dx.doi.org/10.3390/molecules171012341

31. AOAC Official Method 925.10. Solids (total) and moisture in flour. Rockville, MD, USA: AOAC International; 1995.

32. PN EN ISO 6886:2009 Animal and vegetable fats and oils determination of oxidative stability (accelerated oxidation test). Warsaw, Poland: Polish Committee for Standardization; 2009 (in Polish).

33. EN ISO 660:2009. Animal and vegetable fats and oils - determination of acid value and acidity. Geneva, Switzerland: International Organisation for Standardization (ISO); 2009.

34. EN ISO 3960:2010. Animal and vegetable fats and oils - determination of peroxide value - iodometric (visual) endpoint determination. Geneva, Switzerland: International Organisation for Standardization (ISO); 2010.

35. Czaplicki S, Tańska M, Konopka I. Sea-buckthorn oil in vegetable oils stabilisation. Ital J Food Sci. 2016;28:412-25. http://dx.doi.org/10.14674/1120-1770\%2FIJFS.V252127
36. Li H, Song C, Zhou H, Wang N, Cao D. Optimization of the aqueous enzymatic extraction of wheat germ oil using response surface methodology. J Am Oil Chem Soc. 2011;88: 809-17. http://dx.doi.org/10.1007/s11746-010-1731-6

37. Neđeral Nakić S, Rade D, Škevin D, Štrucelj D, Mokrovčak Ž, Bartolić M. Chemical characteristics of oils from naked and husk seeds of Cucurbita pepo L. Eur J Lipid Sci Tech. 2006;108:936-43. http://dx.doi.org/10.1002/ejlt.200600161

38. Nawirska-Olszańska A, Kita A, Biesiada A, Sokół-Łętowska A, Kucharska AZ. Characteristics of antioxidant activity and composition of pumpkin seed oils in 12 cultivars. Food Chem. 2013;139:155-61.

http://dx.doi.org/10.1016/j.foodchem.2013.02.009

39. Procida G, Stancher B, Cateni F, Zacchigna M. Chemical composition and functional characterisation of commercial pumpkin seed oil. J Sci Food Agric. 2013;93:1035-41. http://dx.doi.org/10.1002/jsfa.5843

40. Srbinoska M, Hrabovski N, Rafajlovska V, Sinadinović-Fišer S. Characterization of the seed and seed extracts of the pumpkins Cucurbita maxima D. and Cucurbita pepo L. from Macedonia. Maced J Chem Chem Eng. 2012;31:65-78.

41. Hrabovski N, Sinadinović-Fišer S, Nikolovski B, Sovilj M, Borota O. Phytosterols in pumpkin seed oil extracted by organic solvents and supercritical $\mathrm{CO}_{2}$. Eur J Lipid Sci Tech. 2012;114:1204-11.

http://dx.doi.org/10.1002/ejlt.201200009

42. Ryan E, Galvin K, O'Connor TP, Maguire AR, O'Brien NM. Phytosterol, squalene, tocopherol content and fatty acid profile of selected seeds, grains, and legumes. Plant Food Hum Nutr. 2007;62:85-91.

http://dx.doi.org/10.1007/s11130-007-0046-8

43. Neđeral S, Škevin D, Kraljić K, Obranović M, Papeša S, Bataljaku A. Chemical composition and oxidative stability of roasted and cold pressed pumpkin seed oils. J Am Oil Chem Soc. 2012;89:1763-70. http://dx.doi.org/10.1007/s11746-012-2076-0

44. Barros M, Fleuri LF, Macedo GA. Seed lipases: sources, applications and properties - a review. Braz J Chem Eng. 2010: 27:15-29. http://dx.doi.org/10.1590/S0104-66322010000100002

45. Ardabili AG, Farhoosh R, Haddad Khodaparast MH. Chemical composition and physicochemical properties of pumpkin seeds (Cucurbita pepo subsp. pepo var. Styriaka) grown in Iran. J Agric Sci Technol. 2011;13:1053-63.

46. Joint FAO/WHO Food Standards Programme. 24th Session of Codex Alimentarius Commission. Geneva, Switzerland; 2-7 July 2001; Report of the 17th Session of the Codex Committee on Fats and Oils; 19-23 February 2001; London, UK. 